\title{
Guldpiger og Teknikdrenge \\ - køn i teknisk skole og dets konsekvenser
}

Af Tea Malthesen

og RIKKE SøRENSEN

På teknisk skole forbindes kønnene med bestemte uddannelsesretninger. En konsekvens af dette er uligheder mellem mand og kvinder, men også uligheder mellem forskellige maskuliniteter og forskellige femininiteter. Hvordan foregair denne sammenvevning affag og kon, og hvad betyder den for eleverne?

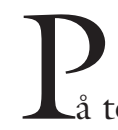

kommer sammenfletningen mellem fag og køn eksempelvis til udtryk således:

En studievejleder forteller, at pigerne på skolen kaldes for Guldpigerne og drengene for Teknikdrengene. Guldpiger fordi pigerne gerne vil uddannes til guldsmede og Teknikdrenge fordi drengene gerne vil uddannes til teknikere. Vi tenkte, at der altså ikke er drenge, der uddanner sig til guldsmed, eller piger, der uddanner sig til teknikere (fra deltagende observation).

Mødet med eleverne i forbindelse med vores deltagende observation på teknisk skole tegner imidlertid et mere komplekst billede af både køn og fag. Det er sammenvævningen mellem fag og køn og dens betydning, vi retter fokus mod i denne artikel. Indledningsvist ser vi på teknisk skoles position imellem eleverne og det kønnede arbejdsmarked, derefter behandles praktikpladsmanglen som en kønnet problematik og dens betydning for forskelligt mærkede 
elever. Herefter beskrives infiltrationen mellem køn og fag på teknisk skole. I forlængelse heraf viser vi elevforhandlinger, der involverer en række sociale kategorier og udfordrer sammenvævningen mellem køn og fag og giver anledning til hierarkiseringer mellem eleverne. Herefter eksemplificeres det, hvordan en lærer er med til at reproducere hierarkiseringer mellem eleverne. Dernæst udfoldes sammenvævningens betydning for elevernes mulighed for at gennemføre den påbegyndte uddannelse. Slutteligt behandles hierarkiseringer mellem de feminint mærkede elever. ${ }^{2}$

Artiklen er baseret på empirisk materiale indsamlet i en klasse, der startede på grundforløbet Håndværk og teknik, vinteren 2006. Forløbet er en fælles indgang for elever, der ønsker at blive industriteknikere, CNC-teknikere, gravører, guldsmede, sølvsmede og redelstensfattere. ${ }^{3}$ I den klasse vi fulgte, startede der 20 elever. 14 elever var feminint mærkede, der alle ønskede at blive guldsmede, 6 elever var maskulint mærkede, heraf ønskede 3 at blive teknikere, 2 ønskede at blive guldsmede, og 1 ønskede at blive gravør (Malthesen og Sørensen 2006). I Danmark var den gennemsnitlige fordeling af elever, der begyndte på Håndværk og teknik i 2005 således, at $14 \%$ af eleverne var feminint mærkede og $86 \%$ maskulint mærkede (Danmarks Statistik). ${ }^{4}$

\section{TEKNISK SKOLE - MELLEM ELEVERNE OG DET KØNNEDE ARBEJDSMARKED}

Når unge vælger teknisk skole som deres uddannelsesvej, vælger de samtidig et erhverv, og dermed relaterer de sig til det kønnede arbejdsmarked. En af teknisk skoles samfundsmæssige opgaver er at producere elever, der kan indgå i arbejdsmarkedet. Således kan de tekniske skoler ses som bindeleddet mellem arbejdsmarkedet og eleverne. Det tilstræbes på de tekniske skoler at ansætte lærere, der kommer fra håndværksmæssige miljøer, så de kan bringe arbejdsmarkedets kulturer med sig ind på skolen (Undervisningsministeriet 2005) og dermed forberede eleven på mødet med kulturen på den kommende praktikplads.

Arbejdsmarkedskulturer gennemsyres af køn i alt fra fag, stillinger og arbejdsområder til kompetencer og interesser (Faber 2004), men skolen har dog ingen intention om at dyrke det monokønnede 5 ved arbejdsmarkedskulturerne. Skolen er stillet i et dilemma. På den ene side skal den viderebringe arbejdsmarkedskulturer til eleverne, på den anden side er skolen også i en position, hvor den har mulighed for at forhandle vilkårene for praktikpladserne og må derfor forholde sig kritisk til disse kulturer. Forhandlingspositionen betyder, at skolen kan være med til at forme det fremtidige arbejdsmarked. Dermed kan skolen ses som splittet mellem forhandlingspositionen og det at sikre egen legitimitet og "levere" elever, der kan indgå på arbejdsmarkedet. På den skole, vi har været, er realiteten, at ideer om køn fra arbejdsmarkedet ubemærket og ikke italesat siver ind på skolen. Dette sker gennem forestillinger om fagene og reproduktionen af de kulturer, der knytter sig til dem.

\section{FORSKELSSÆTTELSER}

MELLEM KØNNENE OG

KØNNET PRAKTIKPLADSMANGEL

Som led i uddannelsen skal eleverne i praktik, men der er stor forskel på udbuddet af praktikpladser på uddannelsesretningerne. Hvor det for teknikere og gravører er relativt uproblematisk at erhverve sig en praktikplads, er der for guldsmede og xdelstensfattere kun praktikpladser til omkring $10 \%$ af de optagne elever (Malthesen og Sørensen 2006). Når de maskulint mærkede oftest vælger teknikuddannelserne, og de feminint mærkede oftest vælger designuddannelserne, betyder det, at de feminint mærkede elever rammes hårdt af praktikpladsmanglen.

At elever, der skal være teknikere, har nemt ved at få praktikpladser, giver dem et 
udvidet mulighedsrum i skolen set i relation til det, der gør sig gældende for designeleverne. Teknikeleven Mads demonstrerer dette udvidede mulighedsrum:

\section{Mads laver ingenting på et tidspunkt. Design-} laveren Kasper kommer forbi og siger, at Mads skal gà videre til den neste opgave, nàr han bliver fardig med en opgave. Han spørger Mads, hvordan det går på teknikverkstedet, og Mads siger, det går fint. Kasper går videre, mens Mads bliver siddende og laver ingenting lidt tid, inden han gair i gang. Mads begynder at brokke sig bojlydt: "Hvorfor fanden skal vi også lave saidan noget lort? Det er for andssvagt” (fra deltagende observation).

Mads' mangel på interesse for designfaget udløser hos læreren en interesse for, hvordan Mads klarer sig i teknikværkstedet. Vi oplevede ingen feminint mærkede elever, der havde en ligegyldig attitude over for designfaget, idet disse elevers praksisser i dette fag var præget af høj koncentration og konkurrence. En konkurrence som de maskulint mærkede elever ikke syntes at blive en del af, heller ikke dem der ville være guldsmede. For Mads var det vigtigst at gøre det godt i teknikfagene, mens han kunne slappe relativt af $\mathrm{i}$ designrelaterede fag. Til forskel fra designeleverne kan teknikeleverne koncentrere sig om faget teknik og være gode til det, for det er det, de skal kunne på deres praktikplads. Designeleverne derimod må på grund af den hårde konkurrence om praktikpladserne være gode $\mathrm{i}$ designværkstedet såvel som i teknikværkstedet (Malthesen og Sørensen 2006).

Man skulle tro, at designdrengene indgik i daglige sammenligninger med de feminint mærkede elever, men på en eller anden måde var det som om, de ikke gjorde. De blev nærmest overset af deres feminint mærkede medelever og til dels også af lærerne. Selv syntes de også at tage det mere stille og roligt i forhold til konkurrencen på designfagene. Vi peger på, at flere forhold gør, at de maskulint mærkede designelever kan gli- de relativt let udenom konkurrencen. Det udvidede mulighedsrum for teknikelever kan smitte af på de maskulint mærkede designelever. Desuden kan det forhold, at de maskulint mærkede elever mere uproblematisk kan skifte til tekniklinien (hvilket vi vender tilbage til om lidt), hvis de ikke får en praktikplads, også spille ind på, at de kan glide udenom konkurrencen.

\section{FAGENE KØNNES OG KØNNENE FAGLIGGØRES \\ - SAMMENFLETNING AF FAG OG KØN}

På teknisk skole fungerer kønnet som et usynligt strukturerende princip, således at ideer om køn og ideer om fag flettes sammen. Gennem denne sammenfletning monokønnes fagene. Teknik er et af de erhverv, der betragtes som et mandefag, og på den tekniske skole reproduceres det som et mandefag. Mens designfaget manifesteres som et kvindefag, på trods af at der er maskulint mærkede elever, der vælger det, og maskulint mærkede lærere, der underviser i det (Malthesen og Sørensen 2006). Teknikværkstedet og teknik som undervisningsfag kønnes maskulint, og designværkstedet og undervisningsfaget design kønnes feminint (jvf. eksemplet med Mads i det foregående afsnit, som viser hvorledes denne kønning kan komme til udtryk). Denne sammenvævning af fag og køn betyder, at indholdsudfyldningen af kategoriseringerne teknikelev og mand sammenvæves, ligesom indholdsudfyldningerne af kategoriseringerne kvinde og designelev sammenvæves (Malthesen og Sørensen 2006).

Ideer om, hvilke evner, interesser, omgangstone og påklædning en feminint mærket elev har eller bør have, er i tråd med ideer om en guldsmed. Ligeledes flyder ideer om maskulint mærkede elever og teknikere sammen. Fag og køns infiltration betyder også, at særlige faglige kompetencer, interesser og opgaver konnoteres henholdsvist maskulint eller feminint i skolen (Søndergaard 2000 og 1996). Det vil sige, at de 
Jan und Casper Luiken: "De Kleermaaker", 1694. 
forståelser af køn, der forhandles på skolen, samtidig er forhandlinger af, hvordan man skal gøre sig som henholdsvis genkendelig6 designelev og teknikelev. Samtidig bliver forhandlingerne af hvilke betydninger, der knyttes til henholdsvis teknik og design, implicit en forhandling af køn. Der foregår forhandlinger af, hvordan fagene kan kønnes, altså hvilke betydningstilskrivelser, der skal knyttes til kønnene, og hvilke kønnede betydninger, der skal knyttes til fagene (Malthesen og Sørensen 2006). Men køn som strukturerende princip er ikke til forhandling på denne tekniske skole.

\section{FORHANDLINGER OG HIERARKISERINGER}

$\mathrm{Paco}^{7}$ er en maskulint og etnisk mærket elev, der forhandler sammenvævningen af fag og køn. Blandt andet gennem sin kropslige selvfremførelse med lyserøde strømper, sølvsmykker, multifarvede pludderbukser, sin interesse for design og sit utraditionelle erhvervsvalg. Han udfordrer kategorierne: Seksualitet, køn, fag og religiøsitet og deres sammenfiltninger i skolen, og han kan blive svært genkendelig på flere måder. Dels tages han ofte for at være indvandrer og muslim, dels bliver han nogle gange kaldt bøsse af de andre maskulint mærkede elever.

En elev, der til Pacos irritation kalder ham bøsse, er den på mange måder let genkendelige Mikkel. Mikkel, der vil være teknikker, fremviser ugenert sine kompetencer, er robust af kropsbygning, lyst kropsmærket, karseklippet og har erfaringer fra arbejdet på værkstederne. Mikkel synes at føle sig udfordret af Pacos påklædning og måske også det, at Paco uproblematisk indgår i kammeratskab med andre maskulint mærkede elever, hvorimod de synes at vige udenom Mikkel, når de danner venskaber. Derudover kan Mikkel også tænkes udfordret af, at Paco er genstand for flirtende opmærksomhed fra nogle af klassens feminint mærkede, som Mikkel selv viser inter- esse for. På flere måder forhandler eleverne kategoriernes betydningsudfyldelse og deres positioner $\mathrm{i}$ forhold til hinanden. I det følgende er det øvelserne i teknikværkstedet, der giver anledning til hierarkisering:

Paco lufter for de andre elever, at han synes, de ovelser, de skal lave i teknikverkstedet, er svere. Mikkel siger hurtigt: "Det er da perelet". Paco holder fast $i$, at der er for kort tid til opgavelosningen. Mikkel siger, at der er for lang tid, det gor det kedeligt for ham, fordi det er for nemt. Mikkel siger, at det mà vere kedeligt for "tøserne", da de jo skal koncentrere sig $i$ designverkstedet. Ingen af eleverne reagerer $p a \dot{a}$, at Paco også mà tenkes at vere en af de elever, der bor koncentreve sig $i$ designverkstedet, eftersom det er knyttet til den linie, han skal folge. Og ingen reagerer pa, at Paco kategoriseres som feminint morket (fra deltagende observation).

Denne forhandlingssituation imellem Paco og Mikkel er et eksempel på, hvordan en udfordring af, hvordan man(d) forholder sig til teknikfaget, også aktiverer kønskomponenten, og forhandlingen bliver en del af det lokale hegemoni imellem maskuliniteter (Hegnhøj 2004). Mikkel bruger her den naturaliserede sammenfletning mellem fag og køn til at positionere sig overordnet i forhold til Paco ved at hævde sig både fagligt og som mere maskulin.

\section{SKOLEN OG LÆRERNE SOM MEDSPILLERE I KØNNEDE HIERARKISERINGER}

Kaj er en lærer8 med erhvervsfaglig baggrund. Dermed personificerer han ønsket om, at lærerne i teknisk skole kender til de arbejdsmarkedskulturer, som eleverne skal møde i deres praktikpladser. Den følgende episode viser, hvordan særlige maskuliniteter kan bæres frem i skolen, qua en lærers maskulinitetsform, og hvordan andre maskuliniteter og feminint mærkede elever herved underordnes:

Tessa og laveren Kaj sidder lange bojet over Tes- 
sas papirer. Hun har svert ved at lave de tekniske tegninger, og Kaj forsoger at hjolpe hende. Mikkel, Tessas sidemand, kigger med og kommer også nu og da med kommentarer. Tessa forklarer, hoordan bun har forstået, at tegningen skal udfores. Mikkels kommentar er: "Det er jo pigelogik”. Tessa har altså misforstået noget. Tessa protesterer ikke over ordet pigelogik. En pige $i$ norheden protesterer. Kaj siger henvendt til Mikkel: "Så skal du hore, nàr jeg siger sådan noget derhjemme - jeg har tre piger...”. Senere $i$ samme time er der en, der siger: "Det er jo logik for kyllinger". Kaj siger ned til Mikkel på bagerste rekke: "Bare det ikke er kvindelogik, hva'?”, og de griner (fra deltagende observation).

Mikkel og Kaj bekræfter hinanden som sidestillede og manifesterer deres sidestilling gennem brug af denne jargon (Søndergaard 2000 og 1996). Forhandlingerne af mas-kulinitet i den tekniske skole er lokale og specifikke forståelser og hierarkiseringer af maskuliniteter, samtidig med at de er relateret til samfundsmæssige forestillinger om kønnene (Connell 2000).

Jargonen er med til at sætte forskelle mellem maskuliniteter, og samtidig gør den, at feminint mærkedes faglighed og interesser kan føles forklaringskrævende. De feminint mærkede elever bliver til de udenforstående, de overforstillede - de underordnede (Søndergaard 2000 og 1996; Haavind 2000). Ulighed mellem kønnene hænger således også sammen med uligheder og forskelssættelser inden for kønnene.

\section{EN VALGSITUATION DIRIGERET AF KØN - EN KØNNET MULIGHED}

I skolen produceres forskellige vilkår for feminint og maskulint mærkede elever. Det drejer sig blandt andet om mulighederne for at fastholde uddannelsesvalget. Undervisningsministeriet lægger op til, at grundforløbet skal være en valgperiode, hvor eleverne kan fă en ide om, hvad de forskellige erhverv uddannelsen kan føre mod, og hvor de kan træffe deres endelige beslutning om erhvervsvalg (Illeris 2002). Men i realiteten fungerer denne periode kun for en af eleverne som en periode, der åbner for refleksioner over erhvervsvalget. Ingen feminint mærkede elever overvejer at blive teknikelever, og ingen maskulint mærkede elever overvejer at skifte til designlinien.

Designeleven Dannie ser en mulighed for at skifte til tekniklinien, hvis han ikke finder en praktikplads. Herved kan han undgå et totalt uddannelsesskift og oven i købet spare tid i uddannelsessystemet (Malthesen og Sørensen 2006). Når nu Dannie begynder at kunne se sig selv som tekniker, hvorfor kan de andre fra hans designhold, de feminint mærkede elever, ikke også gøre det?

Dannies overvejelser om at blive teknikelev kan ses som en åbenlys mulighed for en uproblematisk og genkendelig kobling af køn og fagfelt. En mulighed der åbner sig qua hans kendskab til faget og hans kropsmærke. Dette er en kønnet mulighed, der ikke åbner sig for de feminint mærkede elever, idet sammenvævningen af teknik og maskulinitet ikke lokker dem mod den forklaringskrævende kobling mellem femininitet og teknik. I denne forbindelse skal det siges, at der heller ikke er en eneste feminint mærket elev på skolen, der er teknikelev.

Med desire-begrebet ${ }^{9}$ (Søndergaard 2002) kan vi forstå elevernes uddannelsesvalg som konstitueret i relation til tilgxngelige tænkemåder herunder den lokale sammenvævning af fag og køn. Line Lerche Mørck peger på vigtigheden af, at eleverne kan identificere sig med deres uddannelse (Mørck 2003), altså at de kan se sig selv eller forstå sig selv som guldsmed eller tekniker. Dette er centralt for elevernes incitament til at fastholde uddannelsesvalget, og denne mulighed præges som vist i høj grad af deres køn og den måde, eleven gør det på.

Maskulint mærkede elever, der vælger tekniklinien, er en elevgruppe, der relativt 
nemt kan komme til at forstå sig selv som teknikere, idet forestillinger om deres køn og fagvalg uproblematisk fletter sig sammen. Maskulint mærkede, der vælger designlinien, mindes til tider om, at de er på kønnet udebane. De bliver overset og behandlet med ligegyldighed samtidig med, at de kan undslå sig konkurrencen, som deres feminint mærkede medelever må kæmpe med. Til andre tider opfordres de af klassens øvrige maskulint mærkede til "kampe", hvor både køn og fag forhandles, og hvor det tydeliggøres, at designdrengenes fagvalg ikke uproblematisk er flettet sammen med deres køn.

En måde for disse maskulint mærkede at overkomme noget af det forklaringskrævende i fagvalget på og dermed legitimere sig som maskuline er ved at indgå $\mathrm{i}$ venskaber med klassens andre drenge. Venskaberne mellem de maskulint mærkede understøtter deres maskuline legitimitet men ikke forståelsen af dem selv som kommende guldsmede, som det eksempelvis ses i nogle af venskaberne mellem feminint mærkede (Malthesen og Sørensen 2006). Dermed slører de monokønnede venskaber elevernes forståelse af sig selv i relation til og afhængigt af deres valg af monokønnet fag. På den anden side kan man sige, at designdrengene har kendte maskulint mærkede guldsmede og en maskulint mærket designlærer at identificere sig med. Designdrengenes muligheder for at forstå sig som guldsmede er således mangetydige.

\section{FORSKELSSÆTTELSER - STIL, SMYKKER OG HEGEMONISK FEMININITET}

Stil aktualiseres i teknisk skole som et anliggende for de feminint mærkede designelever, og nogle elever synes at få patent på at definere, hvad der er stil, mens andre ikke har adgang til dette. Stil kan både handle om elevernes måde at udtrykke egen krop på gennem kropsligt tilbehør og om, hvad de gør med kroppen (Skeggs 1997), men det kan også handle om, hvordan skolear- bejde som xskeudformning og udstillingsstande kan gøres.

Sammenhængen mellem femininiteter og stil bygger vi dels på Skeggs’ (1997) pointe om, at forskellige femininiteter har forskellige fornemmelser for og forholdemåder til stil, og at dette knytter sig til klassemæssige baggrunde. Dels på Stormhøjs (2002) forståelse af stil som et tegnsystem, der kommer med udsagn om positioner inden for det konkrete felt, hvor de enkelte tegn indgår i forskelsrelationer til andre tegn. Stil forstås som komplekse systemer eller koder, hvor også opførsel og klasse flettes ind og giver betydning til de enkelte individers mulighed for at blive anerkendte som havende stil (Skeggs 1997).

Eleven Maj forklarer os om stil og tøj i klassen, og om hvordan hun ser det i sammenhæng med positioner blandt klassens piger:

“...jeg vil jo nok gerne accepteres ik? [...] Jeg har det sådan, at jeg kan kigge lidt på mig selv og kigge lidt på dem og blive lidt flov over, at jeg ikke har sådan noget pent toj på. [...] ...jeg tror bestemt ikke, at de vil se ned på mig, fordi jeg kom i gamle sakke vel, men de snakker jo beller ikke så meget med Marie [...] nàr man kigger på det, sà snakker de jo ikke-bun er ikke $i$ deres gruppe - nu tager jeg lige Mariebun er jo lidt speciel - ikke fordi der er noget galt $i$ det, men saidan $i$ forhold til alle os andre, har sådan lidt sjove nederdele på og går $i$ det, hun vil, det er ikke det, der folger moden." (Fra interview med designelev Maj).

På teknisk skole bruges bestemt tøj, smykker, make-up og frisurer til at tegnsætte sig som en designelev med fornemmelser for mode- og smykkebranchen.

Elevernes forholdemåder til stil aktualiseres også i relation til faget. I en opgave skulle eleverne udstille deres produkter på små stande. Her bliver det tydeligt, hvordan man som elev forholder sig til og kan afkode stil og bruge den i den faglige opgave: 
Gangen er omdannet til udstillingslokale med ca. ti udstillinger. De to grupper med designelever har fremstillet emballage, designet alternative pengeklips og pyntet udstillingsstande. ${ }^{10}$ Udstillingsstandene er borde dakket af velour $i$ morke farver, nogle borde er pyntet med stearinlys, blomsterbuketter og en med en konditorkage. De fleste asker er formet $i$ gråt eller sort karton $i$ enkelt design, som krever en vis fingerferdighed. Den ene gruppe har lagt deres esker ind $i$ et koleskab. På køleskabet er der sat en seddel op, hvor der står "cool cash". Ved siden af stair et bord dekket med en pokerdug, jetoner og kort. Her er de alternative modeller stillet op, med morkerne hjerter, spar, klor og ruder. (Fra deltagende observation).

En af grupperne havde lavet deres stand på en måde, der adskilte sig fra de andre gruppers:

\section{Gruppen bavde lavet asker til pengeklipsen $i$ farvestrålende karton med et dyremotiv på, de havde skrevet deres skilt $i$ hainden, og de havde udsmykket standen med blomster klippet $i$ far- vestrålende karton. Gruppen modte efter ud- stillingens afslutning modstand fra nogle af eleverne fra parallelklassen, der buede af dem (fra deltagende observation).}

Gruppens medlemmer har ikke formet opgaven passende, de demonstrerede ikke sans for stil, og de bliver forklaringskrævende designelever. Designeleverne bliver gennem deres forholdemåde til stil mere eller mindre genkendelige designelever, og med relationen mellem stil, femininitet og klasse, som vi tidligere pegede på, bliver det bestemte femininiteter, som bliver mere rigtige end andre, når den faglige opgave udformes.

Den faglige dygtighed ser ud til at spille en større rolle i femininitetskampene end i maskulinitetskampene, og fagligheden handler for de feminint mærkede også om at have fornemmelser for stil og branchen og om at tegnsætte sig selv således. Femininiteter med en særlig fornemmelse for den lokale stil synes således at blive lettere genkendelige i skolen.

\section{OPSAMLENDE}

På teknisk skole fungerer køn som et usynligt og strukturerende princip ved, at ideer om henholdsvis køn og fag flettes sammen. Herved knyttes køn til særlige uddannelsesretninger, ligesom undervisningsfag, kompetencer, interesser og værksteder kønnes, og fagene monokønnes. Den måde, som teknisk skole kønnes på, får konsekvenser for eleverne, der overordnet handler om, at der gives ulige muligheder mellem teknikog designelever og ulige muligheder internt mellem forskellige femininiteter og forskellige maskuliniteter. Der er ulige adgang til praktikpladser for teknik- og designelever, og da eleverne fordeler sig kønnet på fagene, giver det maskulint mærkede elever et udvidet mulighedsrum for at tage den med ro i skolen, mens feminint mærkede elever må konkurrere om praktikpladserne. Qua praktikpladsmanglen sker en forskelssættelse mellem de feminint mærkede, der gør disse elevers forståelse af sig selv i relation til faget særlig vigtig for, at de kan fastholde uddannelsesvalget. Dermed bliver måden, hvorpå eleverne gør deres femininitet, væsentlig for at blive genkendelig som guldsmed in spe og deres mulighed for at forstå sig selv i relation til det valgte fag.

Elever kan blive svært genkendelige som design- eller teknikelever, hvis de kombinerer fag og køn på tværs af de monokønnede forestillinger i teknisk skole, eller hvis de ikke gør deres køn i tråd med de forestillinger, der med fag og køns sammenvævning knyttes til kønnet. Disse elevers muligheder for at forstå sig selv som henholdsvis tekniker eller guldsmed er besværliggjorte, og dermed har eleverne i teknisk skole ulige muligheder for at fastholde uddannelsesvalget.

Maskulinitetskampe og femininitetskampe er uadskillelige fra faglige kampe mellem eleverne. Det hænger blandt andet sammen 
med, at særlige femininiteter og maskuliniteter støttes upåagtet i skolen qua deres genkendelige gørelse af faglighed og køn. Eleverne, lærerne, skolen som institution og arbejdsmarkedet er medspillere i kampene og dermed med til at konstruere hegemonierne.

Vi peger på en sammenhæng mellem fagenes monokønning og produktion af snæverhed i muligheder for at gøre køn genkendeligt. Undervisningsministeriet, skolerne og skolernes lærere må forholde sig til de ulige muligheder, der på forskellig vis er for henholdsvis feminint og maskulint mærkede elever i teknisk skole. Desuden må de se sig selv som en forhandlende part i relation til det kønnede arbejdsmarked, til trods for de dilemmaer de i forvejen har med positionen imellem elever og arbejdsmarked. Det videre spørgsmål bliver, hvordan man kan arbejde med opløsningen af de viste kønnede barrierer i de tekniske skoler, under medtænkning af relationen til det kønnede arbejdsmarked?

\section{NOTER}

1. Feltarbejdet bestod af et seks ugers forløb med deltagende observation i en nyopstartet klasse fulgt op af individuelle interviews med tre elever. Feltarbejdet var en del af udarbejdelsen af vores speciale om elevers fællesskaber og subjektiveringer i teknisk skole.

2. Begreberne feminint og maskulint mærkede er hentet fra Dorte Marie Søndergaard (2000/1996) i stedet for betegnelserne kvinder og mænd. Dette for at undgå de konnotationer, der kan knytte sig til begreberne kvinde og mande. Samtidig minder betegnelserne feminint og maskulint mærket os om, at køn er en konstruktion.

3. Dette grundforløb fører mod 35 forskellige uddannelser (Københavns Tekniske Skole 2006b). Efter grundforløbet kan eleven følge et af fire hovedforløb: Industritekniker, Metalsmed, Værktøjsmager eller Ædelsmed (Københavns Tekniske Skole 2006a). Ædelsmed er en samlet betegnelse for guld- og sølvsmed. I 2005 begyndte 306 elever på hovedforløbet Industritekniker, $4,6 \%$ af disse ele- ver var feminint mærkede, 3 elever påbegyndte hovedforløbet Metalsmed, en af disse var feminint mærket, 45 elever påbegyndte hovedforløbet Værktøjsmager, en af disse elever var feminint mærket, 30 elever påbegyndte uddannelsen som Ædelsmed, 43,3\% af disse var maskulint mærkede (Danmarks Statistik).

4. I 2005 påbegyndte 3178 elever grundforløbet Håndværk og Teknik i Danmark (Danmarks Statistik).

5. I begrebet monokønnet ligger, at et område, miljø eller lignende kun varetages, bruges og forbindes af og med individer af samme køn (Kaare 1999).

6. Genkendelighed er en udledning af begrebet kulturel genkendelighed, som vi bruger inspireret af Søndergaard (2000 og 1996). Det refererer til, at et individ udfylder en genkendelig position i en specifik kontekst og dermed bliver genkendt af andre aktører. At blive genkendelig er en forudsætning for integration i den konkrete kultur.

7. Alle navne er ændret af hensyn til elevers og læreres anonymitet.

8. Som et led i specialets afgrænsning har vi fravalgt at udforske lærerperspektivet gennem interviews, hvorfor det udelukkende er representeret, som det kommer til udtryk gennem den deltagende observation.

9. Vi bygger på Søndergaards (2002) desire-begreb, fra hendes artikel "Subjektivering og desire begreber på empirisk arbejde i akademia".

10. Derudover består opgaven i at lave en forretningsplan, med udregninger af udgifter til materialer, løn, priser og overskud. Eleverne făr ikke nogen karakter for denne opgave, men udførelsen vægter i den samlede karakter for hvert fag. Den faglige bedømmelse af standene bestod i, at de forskellige faglærere sagde et par ord ved hver stand.

\section{LITTERATUR}

. Connell, Robert W. (2000): The Men and the Boys. Polity Press, UK.

- Danmarks Statistik: EUD2 Påbegyndte på EUDuddannelser, efter område, uddannelse, alder, uddannelsesform, herkomst og køn. http://www.statistikbanken.dk/statbank5a/SelectVarVal/saveselections.asp . Faber, Stine Thidemann (2004): “Kønsmæssige minoriteter. Når mænd bliver sygeplejersker og kvinder politibetjente", in Kvinder, Køn \& Forskning 2004/4. 
. Haavind, Hanne red. (2000): Kjønn og fortolkende metode. Metodiske muligheter $i$ kvalitativ forskning. Gyldendal, Oslo.

· Hegnhøj, Rikke Randorff (2004): "Flertydige maskuliniteter", in Kvinder, Kon \& Forskning 2004/4.

. Illeris, Knud m.fl. (2002): Ungdom, identitet og uddannelse. Roskilde Universitetsforlag, Roskilde. - Kaare, Jan (1999): "Kvindeskolen: Mænd på Stagstrup Skole har forstået at indrette sig, selvom de er omringet af kvinder. Mænd ud i klasserne", in Folkeskolen 1999/20.

- Københavns Tekniske Skole: Håndvark og teknik - Tandteknikeruddannelsen, www.kts.dk/tuborgvej/

- Københavns Tekniske Skole: Øvrige uddannelser på $H$ og $T$, http://www.kts.dk/uddannelser/eudhaandvaerkogteknik/oevrigeuddannelserhogt.asp - Malthesen, Tea og Sørensen, Rikke (2006): Fallesskaber og subjektiveringer - i teknisk skole. Speciale fra Roskilde Universitetscenter, Roskilde.

- Mørck, Line Lerche (2003): Laring og overskridelse af marginalisering - Studie af unge mond med etnisk minoritetsbaggrund. Ph.d.-afhandling, Danmarks Pædagogiske Universitets Forlag, Emdrup. - Skeggs, Beverly (1997): Formations of Class and Gender. Sage Publications, London.

- Staunæs, Dorthe (2004): Køn, etnicitet og skoleliv. Forlaget Samfundslitteratur, Frederiksberg. - Stormhøj, Christel (2002): "Stil som social identitetsmarkør - en flerperspektivistisk tilgang til unges stil", in Dansk Sociologi 2002/1.

- Søndergaard, Dorte Marie (2000/1996): Tegnet på kroppen. Museum Tusculanums Forlag, København.

- Søndergaard, Dorte Marie (2002): "Subjektivering og desire - begreber på empirisk arbejde i akademia”, in Psyke \& Logos 2002/1.

- Undervisningsministeriet (2005): God praksis for fastholdelse af elever $i$ erhvervsuddannelserne - skolernes erfaringer og eksempler på varktøj, http://pub.uvm.dk/2005/fastholdelse.html . West, Candace \& Don H. Zimmerman (1987): “Doing Gender", in Gender \& Society, 1987/2.

\section{SUMMARY}

The article shows how gender works as an unnoticed principle of organization at a Danish technical school. We point out how ideas of subjects studied and gender are interwoven. As a consequence of this students are given different possibilities at the technical school depending on their choice of subject and their gender mark and the way they do gender at the technical schools. These uneven possibilities can only be understood in relation to the gendered labour market.

Tea Malthesen, cand.scient.soc

Socialvidenskab og Geografi, RUC

Rikke Sørensen, cand.scient.soc

Socialvidenskab ogPsykologi, RUC 